\section{Life in Science}

\section{Abraham Eisenstark}

Email: eisenstarka@missouri.edu

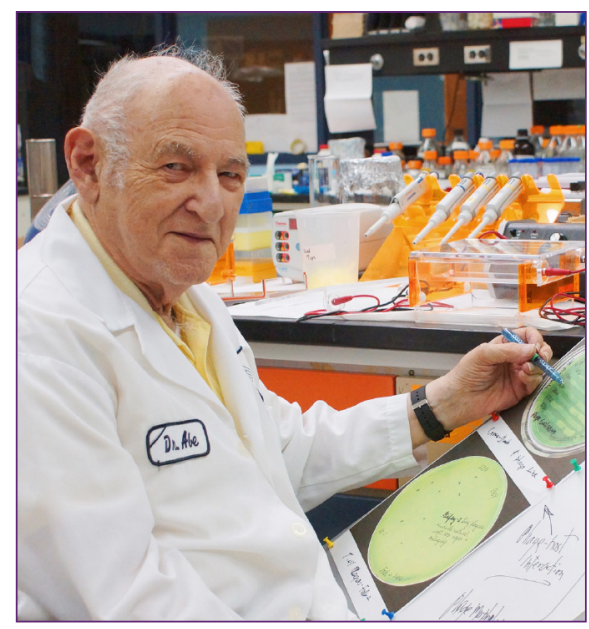

Abraham Eisenstark, Research Director, Cancer Research Center, Columbia, Missouri; Byler Distinguished Professor (Emeritus), University of Missouri; Thomas Jefferson Professor, Univerity of Missouri; Columbia, MO USA

\section{Early Life}

My story started when the ship RMS Saxonia brought my mother and me to Ellis Island in 1921. Our journey brought us to Chicago, where we joined relatives, and continued to Kansas City. This was our exodus from Poland's medieval prejudices to the land of opportunity.

\section{The Influence of Books and Movies}

Addiction to microbiology came early in my boyhood through books and film. First there was the novel Arrowsmith by Sinclair Lewis. In the movie adaptation, actor Ronald Coleman dealt with bubonic plague and quickly became my scientific hero. Throughout the years, my paperback copy of this novel has been loaned to many students. Next, I became fascinated by Paul Muni in The Story of Louis Pasteur. Then there was Microbe Hunters by Paul DeKruif, and Rats, Lice and History by Hans Zinsser. Later came a 1940 biographical film, Dr. Ehrlich's Magic Bullet starring Edward G Robinson.

In addition to these items from popular culture, I was inspired by books from the early years of molecular biology. A particular volume, Molecular Biology of Bacterial Viruses by Gunther S Stent (1963) is still on my shelf and is continually checked out by colleagues and students.

\section{Education}

Following an inspiring science education at Kansas City public schools (including Junior College), I entered the University of Illinois for my $A B$ and $M A$, and to begin a PhD in microbiology. At Illinois, I was trained in electron microscopy (early RCA model) by Dr Martha Barnes Baylor, an inspiring mentor. She had interacted with early molecular biologists, Max Delbrück, Salvador Luria and Sol Spiegelman. Her excitement inspired, not only myself, but other students as well, such as Gunther Stent, who was finishing a PhD in chemistry. Martha and I urged him to seek a postdoc with Delbrück at Cal Tech.

\section{War Years (1942-1945)}

My formal education in medical science was interrupted by war service as Tech Sgt, 8th Medical Laboratory. Malaria was the devastating scourge of soldiers returning from New Guinea to Townsville, Australia, and I was involved in diagnostic procedures. For service in the Pacific, I received a medal for the Battle of Papua, New Guinea.

\section{PhD}

After war service, I eagerly returned to Illinois to finish my PhD. Martha Baylor was leaving for the University of Michigan, and I was appointed to replace her as research assistant in charge of RCA electron microscopy. My first passionate affair was to study virions of Xanthomonas pruni attacking host cells with Dr Thornberry. Four subsequent studies explored $X$. pruni lysogeny and phage fine structure using Hitachi EM at Kansas State University.

\section{Mentors}

My affair with phage received constant stimulations from exposure to bright minds during my $\mathrm{PhD}$, followed by early career days and continues today. At the University of Illinois, there were exciting seminars and evening discussions with visiting molecular genetic giants (Delbrück, Hershey, Sonnenborn, etc). I also attended interviews at U Indiana (Watson, Herman Muller, Luria). Another important aspect was the enlightening discussions and encouragement with
Kansas State $U$ faculty members geneticist Val Woodward, virologist Richard Consigli and molecular biologist Gordon Lark. At several Cold Spring Harbor Symposia, I formed significant relationships, including a long friendship with Joshua and Esther Lederberg, and an association with Miloslav Demerec, McClintock and many other speakers.

This networking continued while on Copenhagen sabbatical (Ole Maaløe lab) with a Guggenheim fellowship. Significant events: 1) U Copenhagen Biological Sciences Building dedication ceremony (1959) with speakers Niels Bohr, Jacques Monod, etc, and, 2) meeting other Nobelists as they stopped in Copenhagen, bound homeward from Stockholm. Later, this was followed by five full summers in Miloslav Demerec's laboratory on Long Island, with a flow of phage P22 transductions in chromosome mapping and biochemical pathway experiments. More recent phage experiments took place while on research leave at the $U$ Paris Jacques Monod Institute, while working in Daniele Touati's laboratory.

A particularly inspiring phage research mentor was Edouard Kellenberger. He, his wife Grete Kellenberger and Nobelist Werner Arber were guest professors at Kansas State $U$ during 1965-1966. Edouard and I shared the mentorship of PhD candidate Sam To, resulting in the publication of a paper discussing the disassembly of T-even bacteriophage into structural sements and subunits. My friendship with Edouard continued when my wife and I were his guests on several visits to Switzerland.

\section{Administrative Jobs}

I managed to juggle research activities while in administrative roles. I spent 15 months in Washington, DC at National Science Foundation as program director for molecular biology (1968-69). There was a constant flow of interactions with top scientists, awardees, and evaluators on numerous site visits. I then moved to $U$ Missouri to head the division of biological science, which contained several disciplines (1971-1980). After mandatory retirement from the University in 1990, I became the director of Cancer Research Center in Columbia, Missouri which had excellent laboratory facilities.

\section{Phage Publications}

While at Kansas State University, with the awareness of use of phage in bacterial typing 
schemes, I had grants to continue my studies of prophage/phage of several bacterial species, including Staphylococci, Klebsiella, Bacillus anthracis, Vibrio cholera, Moraxella (Hemophilus) bovis and E. coli phages mu-1, T3, T4.

As chairman of the ICTV (International Committee on Taxonomy of Viruses) phage subcommittee, I met with virologists from other parts of the world to clarify relationships among phage and other viral species. It was a pleasure to pass the chairmanship to Hans Ackermann. Hans and I co-authored papers on phage taxonomy and morphology.

When I moved my lab to the Cancer Research Center, Columbia, I continued Salmonella phage P22 transduction studies of bacterial chromosome damage and repair. More recently, with post-doctorate Segun Fagbohun, using phage display technology, we published a study of metastatic prostate cancer cell-specific phage-like particles as a targeted gene-delivery system.

Currently, via phage P22 transduction, we have rid Salmonella typhimurium LT2 of pathogenic genes, and inserted tumor-seeking genes. The genetically engineered strain reduces prostate tumors in mice, and we are continuing to use the phage-engineered Sallmonella in dogs with prostate cancers.

\section{Mentoring Roles}

While my passion for phage studies has received constant stimulations from mentors, a great joy has been to mentor numerous students at many levels of personal mentorship as well as in the classroom. My laboratories have fostered high school students, university undergraduates, MSs, PhDs and postdocs. Proudly, each has gone on to professional degrees and positions, where they now passionately pursue scientific careers.

\section{Anticipated Future, Phage Research}

Among future issues, I expect to learn of newly discovered bacteriophage from weird places (sea bottoms, deep into the center of the earth, and perhaps from bodies high in the sky), of phage that unravel more of the mysteries of nature, of phage that destroy disease agents, and of phage (via phage display technology) that serve as basic biochemical and even industrial tools. I look forward to seeing pictures of phage fine structures, learning of their unique functions, and perhaps of phage origins and evolutionary development from the beginning of world history.

\section{A Final Reflection}

My enthusiasm for phage experiments may be explained by a statement by Linus Pauling who said his great joy was to see the results of an experiment and to know that he, and no one else in the world, then knew what he observed. Eureka!! For me, of course, other investigators can then read these results when they are published in a high impact journal, such as Bacteriophage. 